down to them to be treated. When they have intense anemias to deal with the patients are treated in bed, while those with milder cases take the medicine given them and go home. Lvery case is diagnosed by means of the microscope, the stools and blood being carefully studied. Two American physicians have organized and pushed a plan to treat practically the entire population of Porto Rico. Dr. Ashford and Dr. Ling are engaged in this work now, as they have been for a number of months. They were invited to be present at this meeting, but they were detained in the service, and are even now engaged in their splendid work. They ask nothing from us, but their fine service certainly demands from us knowledge of the work and our sympathy. The results have been published in brief, but not in detail in the journals, and are known less widely than they deserve. Dr. Cabot looks on their achievements as destined to be as beneficent as the work of Reed and Carrol on yellow fever in Cuba.

Dr. M. H. Fussell, Philadelphia, asked if Dr. Smith considers the ground itch as the only source of this parasite in the human being, or if the affection may occur by the parasite being swallowed, and whether he has any idea or made any calculations of how many embryos there may have been in the mass that he placed on the patient's wrist. Dr. Fussell understands that the embryo or parasite does not increase in the intestines of the individual. He said that he would also like to know if the blood was examined and the eosinophiles counted.

Dr. Philip King Brown, San Francisco, stated that in San Francisco physicians have experiences with three classes of uncinariasis. The first class came from Mexico, evidently a pure class. Then came soldiers, returning from the Philippines, without having had any symptoms of uncinariasis before discharge. Some of them were kept in the general hospital with amebic infection, and were discharged, but nothing was known regarding the presence of uncinariasis. Many of these cases came to the county hospital. A peculiar thing about some of these soldiers was the striking symptoms that occurred when there were few parasites. Dr. Brown recalled one patient who came near dying of anemia and yet the physicians could find but seven parasites. The third class of eases was found among the Porto Ricans who were sent to the Hawaiian Islands to replace Japanese laborers on sugar plantations. They were not a success, and were returned to San Francisco, where a large majority of them still remain. They present the type of the disease which has been so thoroughly investi. gated by Ashford. Attempts have been made by Gunn of San Francisco, who has studied the cases in San Francisco very thoroughly, to find the parasite in infants born since these Porto Ricans left their native home, but thus far they have not been successful. He has, however, discovered several cases of bilharzia infection in these Porto Ricans.

Dr. Claude A. Smith, Atlanta, Ga., in reply to the questions stated that, while he can not say that the passage of the parasite through the skin is the only way by which it gains access to the human body, yet from the experiments and from the clinical history of the cases this mode of access appears to be the rule and the ingestion through the alimentary canal the exception. In growing the larvæ in the laboratory, it was noticed that they would climb on the sides of the vessel. This would cause us to suspect that they would climb on plants from their natural development in the soil, and if so, it is possible that they might be swallowed by persons eating raw vegetables. He said that it was impossible to count the number of larvæ contained in the soil which he placed on the wrist of the patient. They were intensely concentrated, more concentrated than they would ever develop under natural conditions. There were undoubtedly many thousands in the small amount of soil which he used, as examination under the microscope showed it to be swarming with them. Autoinfection, he said, is practically an impossibility. His experiments indicate that the larvæ will not attempt to enter the tissues before they are four or six days old, and it is not likely that the eggs would remain in the intestines for this length of time, even if they could find conditions suitable for hatching. As before stated, no blood examinations were made in this case, as the patient was just out of the hos- pital, and such examinations, therefore, would have been of uncertain value. Dr. Smith inclines to the view that the parasites pass into the veins and thus get into the circulation. In the experiments the inflammation of the forearms above the eruption appeared more as a phlebitis than a lymphangitis. The children of all classes in the South go barefoot in the summer, and all are subject to the ground itch, but it is most common among the poorer classes in the country. As the better classes are less exposed to the disease, they usually have a mild form which can only be diagnosed by the examination of the feces, and as there are no objective or subjective symptoms these cases are generally overlooked. It is only the severe cases which interfere with the development of the person and which present symptoms of the disease. Those individuals who have had only one or two attacks of ground itch have only a small number of the parasites in the intestines, and these produce no effect on the development of the person. It is only when there have been a number of attacks of ground itch (usually covering a period of several years) that there is any interference with the development of the body. A study of the climatic conditions shows that in many sections the conditions favorable to the development of the parasite occur only two or three times during a summer. When the conditions are favorable for the development of the parasite one will usually find every child of an entire family infected, but usually there is not more than one who has the severe type of the disease. In the majority of the cases of the severe type of the disease, the patient will eventually "outgrow" the disease; that is, the child will begin wearing shoes at 15 or 17 years of age, and from that time on the parasites gradually die out.

\section{IRITIS TUBERCULOSA AS DIAGNOSED AND TREATED BY KOCH'S TUBERCULIN.*}

WILLIAM E. GAMBI.E, B.S., M.D.

Adjunct Professor Ophthalnology and Clinical Ophthalmology, Unirersity of Illinois; Ophthalmic. Surgeon, Cook County Hospital, etc.

AND

I. V. I. BROWN, B.S., M.D.

Associate in Ophthalmology, Rush MedienI College, in Aftiation with the University of Chicago; Tathologist, Illinois Charitable wye and lar Infirmary. CHICAGO.

\section{HISTORY OF THE CASE TREATED. ${ }^{1}$}

Patient.-Mr. M. E. S., a clerk, aged 25, consulted Dr. (xamble Aug. 27, 1904, on account of persistent "redness" of the left eye of four months' duration. At no time had there been severe pain. There was no personal history or evidence of syphilis, and the family history of tuberculosis was negative.

Examination.-This revealed ciliary injection and an irregular pupil which responded poorly to light and dilated irregularly under atropin with the exposure of numerous posterior synechia. A reddish growth the size of a pinhead was discovered springing from the inferior temporal root of the iris. With the aid of a Berger loupe, a second smaller growth was seen above the first and nearer the pupiliary border of the iris. The nodes were semi-transparent and non-vascular. The iris itself was discolored. its markings indistinct and the media hazy. L. vision, 20/70, that of the fellow eye, 20/50) with no improvement by glasses. The patient had a slight cough, an afternoon temperature of 99.5 and slightly subnormal temperature; pulse, 80 ; weight, 117 pounds; he is able to be about his work every day.

A general examination by Prof. W. E. Quine reads as fol. Iows:

(a) Enlarged glands above the inner third of the left

* Read in the Section on Ophthalmology of the American Medical Association, at the Fifty-sixth Annual Session, July, 1905.

1. Whis patient was sbown before the Chicago Ophthalmological Society, Oct. 11. 1904, when the inflammation was at its most llorid stage, and again six months later, March 14, 1905, after an apparent cure had been effected. 
clavicle. (b) Leucopenia-only 3,500 whites-8 per cent. of them small mononuclear and 32 per cent. large mononuclear (i. e., 'relative' lyniphocytosis). (c) A little cough without expectoration or discoverable pulmonary localization. Suggests involvement of the mediastinal glands. (d) No bacilli found in urine. Findings suggest glandular tuberculosis,

Six subsequent examinations of the sputum for tubercle bacilli were negative.

Treatment.-Commencing Sept. 7, 1904, potassium iodid and later mercurial inunctions were used for several weeis. The two nodes not only steadily increased in size and became grayish-opaque, but three alditional nodes appeared in the lower nasal quadrant, ciliary injection became more marked and fine precipitates developed over the lower half of the posterior surface of the cornea. These precipitates were not ar. ranged in the classical triangilar shape characteristic of serous eyclitis but were spread over the entire lower segment without particular form and indicated rather an extension of

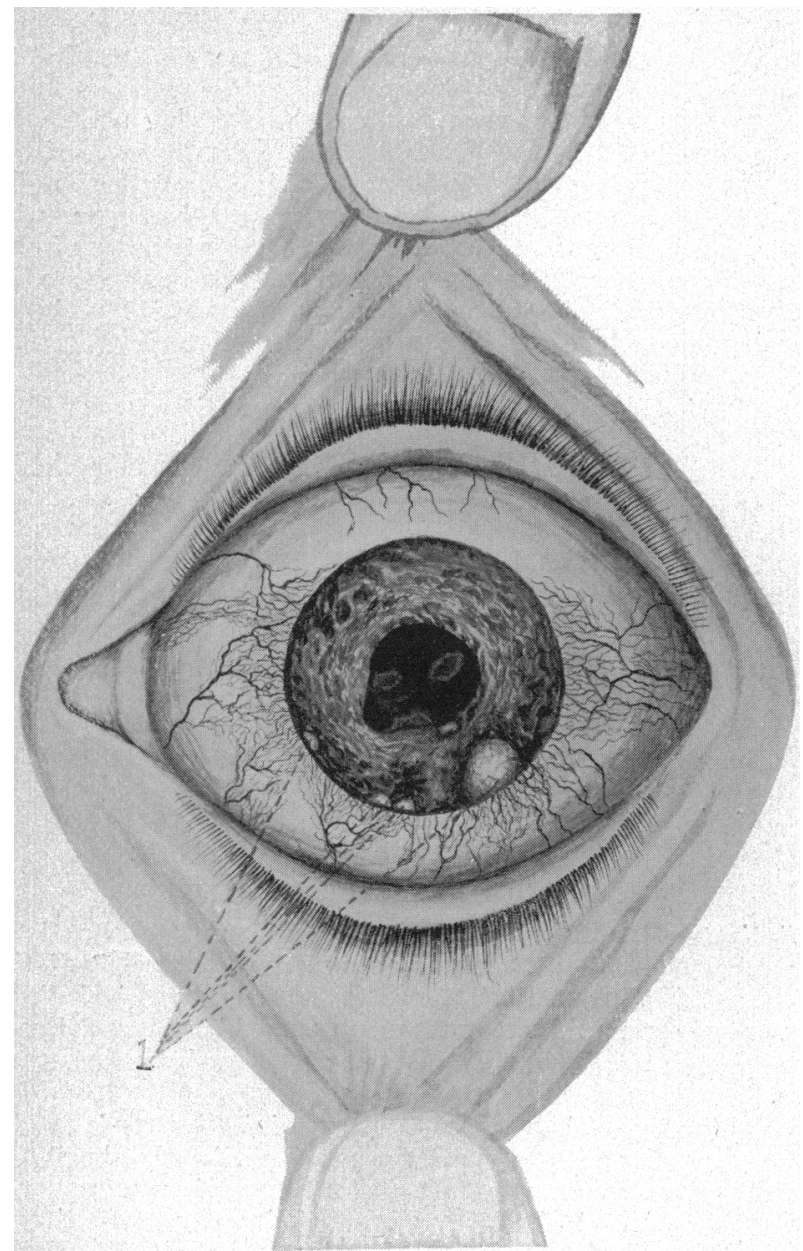

Fig. 1.-Active Iritis Tuberculosa. 1, nodes.

the inflammation from the iris below onto the adjacent cornea. Diagnosis.-Iritis tuberculosa.

Tuberculin Treatment-Oct. 24, 1904, at the suggestion of Dr. Brown, the patient was placed in a hospital and given injections of Koch's new tuberculin ' $\mathrm{T}$. $R$., with the instillation of atropin, as advocated by E. v. Hippel (1904). At this time a drawing of the eye was made (F'ig. 1) and notes on the condition of the eve as follows:

On focal and transmitted lights one finds: (I) Nearly complete circum-corneal injection; (2) that the posterior surface of the cornea, especially the lower half, is dotted by pinhead sized, thin, yellowish-white masses; (3) that a deep, smooth, vascularized, light-yellow, translucent, pad-like, lensshaped node, with flattened anterior surface and sharply convex border is attached by a small, constricted base well down toward the very angle of the iris root beneath the opaque corneo-scleral limbus as if springing from the ligamentum pec- tinatum. The node lies at the lower end of a line drawn through axis 110 degrees, and measures $2.5 \mathrm{~mm}$. in the verti. cal plane, $2 \mathrm{~mm}$. in the horizontal and $2 \mathrm{~nm}$. in the antero posterior plane. At least its superior one-half rides iree over the iris and obscures four-sevenths of the iris surface measured from the root toward the pupillery border. Four smaller nodes about the size of pinheads are seen, two of them seated in the sinus angle below, one nasal, and the fourth at the pupillary border directly above the largest node. The pupil measures $5.5 \mathrm{~mm}$. in its greatest diameter (axis 110 degrees) and is very irregular in outline from nunterous broad posterior synechiæ.

The first injection of $1 / 500 \mathrm{mg}$. of tuberculin $\mathrm{T}$. R. causer no perceptible change in the teniperature and excited no local reaction. Thereon the injections were continued, the temperature being taken every two hours, as follows: October 26: $1 / 500 \mathrm{mg}$., maximum temperature (rectal) during the day 99.8 at $11: 40$ p. m. Oetober 31: $12 / 500 \mathrm{mg}$. at 6 p. m., maximum temperature, $09.2 ; 24$. hours after the injection the tem. perature was 100.6 ; 6 hours later, 100.6. During the morning the piliary injection, especinlly that just below the iris nodes, increased markedly. Vessels now stood out prominently

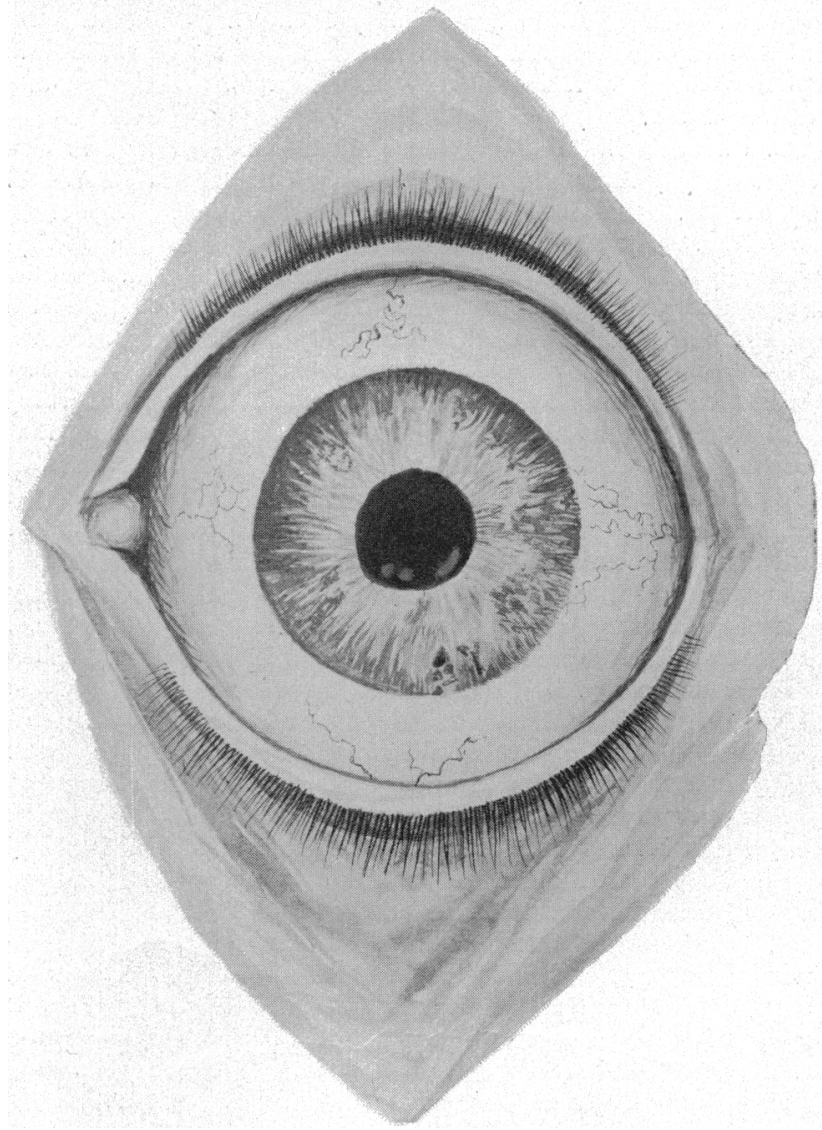

Fig. 2.-Healed Iritis Tuberculosa.

over the surface of the largest node and the patient complained of tenderness of the eye on pressure. This local reaction lasted about 12 hours and then abruptly disappeared. No vember 2: maximum temperature, 99.7; no injection. November 3: maximum temperature, 99.6 ; no injection. November 4: maximum temperature, 99.6 ; no injection. November 5 , $10 / 500 \mathrm{mg}$. at $6 \mathrm{p} . \mathrm{m}$.; no change in the temperature or in the local condition. Injection of $10 / 500 \mathrm{mg}$. of tuberculin $T$. $R$. at $6 \mathrm{p} . \mathrm{m}$. Twenty-four hours later ciliary injection was again increased and completely encircled the nornea; the large node was deeply congested and of a brick-red color, remaining so for several hours. The maximun temperature $(8 \mathrm{p} . \mathrm{m}$.) was 99.8. November 7: 6:40 p. m., temperature, 98.4. Injected $4 \mathrm{mg}$. of tuberculin T. R. for the purpose of obtaining a diagr. nostic reaction. November 8 : maximum temperature, $4 \mathrm{p.} \mathrm{m}$., of 100 , lasting one hour. The large node especially was more hyperemic and the ciliary injection increased. (Reaction not 
considered conclusive.) November 11: The patient left the hospital to report at the office for further treatment.

From Nov. 12, 1904, to May 1, 1905, he continued to receive injections with no untoward effects on the temperature or local conditions. Up to the middle of April a withdrawal of the atropin would cause an immediate increase in the ciliary injection. From this time on one drop a day only was required. Two further attempts were made to secure a tubereulin temperature reaction, and by the use of the old and not the new tuberculin (T. R.), viz.: First attempt Nov. 15, 1904; iemperature, 99 at $12 \mathrm{~m} . ; 4 \mathrm{mg}$. of the old tuberculin injected: about ten hours later the patient experienced a marked chill and his temperature rose to 101.6. ('lemperature reaction considered conclusive).

Second attempt, December 16: Temperature 99, at 10 a.m. Injection of $5 \mathrm{mg}$. of the old tuberculin; 8 hours later there was a maximum temperature of 102 , followed two and one-half hours later by a chill. Soreness of joints, jaundice and poor appetite persisted for two weeks. (Temperature reaction was considered conclusive.)

March 5, 1905: Under the six months' treatment by tuber culin injections and atropin there has been a steady and gradual improvement in the condition of the eye; e. g., all the nodes have entirely disappeared, the iris has regained nearly the color of its fellow, there is no ciliary injection whatever and close work does not redden the eye in the least; vision has improved from $20 / 70$ to $20 / 50$; he has gained 3 pounds in weight and feels quite well, although the afternoon rise in temperature still continues. The appearance of the eye is very accurately represented in Fig. 2.

July 1, 1905: Conditions unchanged; no evidence of the nodes.

Sept. 8, 1905: Eye quiet. Weight, 125 pound, a gain of eight pounds. No temperature for two months past.

\section{SUMMARY OF THE DIAGNOSTIO AND THERAPEUTIC USE OF} TUBERCULIN IN THIS CASE.

We had here, then, a plastic iritis eventuating in the formation of definite nodules. Such nodules may occur in a number of affections, some of which may be excluded at once, as leukemia and pseudoleukemia, by the blood count, and glioma, by the age of the patient. Furthermore, there is no history or evidence of a hair or other foreign body penetrating the eye and causing an iritis nodosa (Saemisch). Syphilis can be excluded with a fair degree of probability by the failure of the potassium iodid and mercury to effect an improvement, and, lastly, leucosarcoma can be eliminated by the markedly inflammatory nature of the affection. Iris nodes caused by other micro-organisms than the tubercle bacillus have been studied experimentally by Sattler ${ }^{2}$ and by Stock, ${ }^{3}$ but have not been proved to occur in man. While, therefore, the diagnosis of iritis tuberculosa may rightly be made by exclusion, it is further and finally established as we think:

(1) By the positive general reaction to tuberculin, as shown in the typical sudden rise and fall of the temperature on two separate occasions, and amounting to 2 and 2.5 degrees respectively (allowing for the daily afternoon rise), accompanied by marked chills, pains in the joints, etc. (2) By the repeated local reaction in the eve when the dose of tuberculin injected had reached the physiologic limit of about $1 \mathrm{mg}$., manifested by a marked increase in the ciliary injection, in the tumefaction and vascularity of the iris nodes. (3) By the persistent afternoon rise of temperature, enlarged supraclavicular glands and slight cough, pointing to a focus of tuberculosis elsewhere, to which that of the eye is probably secondary.

2. Vossins : (1801) Beitr. zur Augenh'l'k. heraugeg. von Deutschmann, 1. p. 142-188.

3. Stock: (1803) Berleht ijber d xrs, Vers. d. Ophth. Gesell. zu Heidelberg, p. 77-99.
REITEW OF THE LITERATURE ON THE USE OF TUBERCLLIN IN THE EYE.

Following the publication of Koch's method in 189n, HeNOCII $^{4}$ reported that he had obtained a marked local and general reaction from tuberculin in a quiet phthisical eye which had been blind for years following a perforating keratitis, and KOEHLER and WESTPIIAL" reported that they had seen a $4 \times 2 \mathrm{~mm}$. peripheral corneal ulcer develop in a normal eye, with profound general reaction, four days subsequent to a single injection of $1 / 100 \mathrm{mg}$. of Koch's lymph.

The next year witnessed the publication of a large number of observations on the use of tuberculin, both for diagnostic and therapeutic purposes, as follows:

ALBRAND ${ }^{3}$ reported tuberculous nodes of the palpebral conjunctiva, with positive inoculation experiments and bacilli findings, absorbed in three weeks by injections of $1 / 1000$ to $3 \mathrm{mg}$; q quiescent 10 months later.

BELLIARD ${ }^{7}$ states that Sulzer obtained a marked local and general reaction in three cases of strumous keratitis with aggravation of the disease.

BoNGaniz ${ }^{8}$ reported two cases of iridocyclitis tuberculosa, with bacilli; no reaction from 3 injections of $1 / 1000 \mathrm{mg}$.; one eye underwent phthisis bulbi and eve had to be enucleated.

$\mathrm{CoHN}^{8}$ (1) No local reaction or improvement, though general reaction in a bilateral dacryocystitis; used three injections of .75 to $1 \mathrm{mg}$. (2) Same results in two cases of phlyctenular keratitis, with interstitial keratitis.

ENSLiN ${ }^{10}$ reported a case of lupus conjunctiva, corroborated by Cohnheim's experiment; temporary improvenient took place, with recurrence and excision. He lised large doses.

GEPNER $^{11}$ reported extensive bilateral lupus conjunctivæ, with ulceration, healed by two injecticns of $1 / 1000 \mathrm{mg}$.

GRADLE $^{12}$ reported three cases: (1) Interstitial ulcerative keratitis, with perforation, influenced by three weeks' injection $(0.15$ to $0.3 \mathrm{mg}$.) with marked local and general reaction. (2) Deep progressive, central corneal ulcer healed in 12 days by two injections ( 0.2 and $0.3 \mathrm{mg}$.) (3) Shallow progres. sive central ulcer of each eye entirely healed on two occasions in 11 and 15 days and by 0.2 and $0.5 \mathrm{mg}$. injections, respectirely.

v. HIPPEL ${ }^{13}$ reported two cases: (1) Obstinate inflamma. tion of each cornea and iids, remarkably improved by one injection of $1 / 200 \mathrm{mg}$. in ten days. (2) Eezematous corneal disease of each eje healed by two injections (1/200 and $3 / 1000 \mathrm{mg}$.), with marked general reaction.

KoEniasiloefer and MaschKE ${ }^{14}$ reported nine cases: (1) Keratitis interstitialis; clearing of opacities in six days by two injections of $1 / 2 \mathrm{mg}$, with local and general diagnostic reaction. (2) Eczematons corneal ulcer; rapid henling following one injection of $1 / 2 \mathrm{mg}$. (3) Ulcer ( 4 by $3 \mathrm{~mm}$.) lealed in 4 days by $1 / 2 \mathrm{mg}$. injection, with local and general reaction. (4) Ulcer of $2 \mathrm{~mm}$. nearly healed in 5 days, with

4. Hewoch: (1890) "Mitiheilungen iiber das Koch'sche Heilrerfahren gegen Tuberculose." Berl. klin. Woch., No. 51, p. i169-1171.

5. Korhler and Westphal: (1890) "Tober die Versuche mit dem von FIerren Geh. Koch gegen tuberculnse empfohlenen Mittel." Deutsene med. Woch., No. 47, p. $1058-1066$.

6. Albrand: (1891) "Erfahrungen iber das Tuberculin aus der l'rofessor Schoeler'schen Augenklinik in Ferlin." Klin. Monatsbl. f. Augen. 1 , o. $149-168$.

7. Belliard: (1891) "Les effets du liquide de Koch dans in keratite strumeuse." Ann. d. Ocul., cri, n. 26.

8. Bongart: (1891) "Teber die Anshreitung der tuberculosen Infection im Auge auf Grund nathologisch Anatomischen Untersnchungen." Inaug. Diss. Wuerzberg. 20 pages.

9. Cohn: (1891) "Notizen über Einspritzungen Koch'scher Fluessig'seit bei Augenleiden." Berl. klin. Woch., No. 7, p. 175176.

10. Fnslin : (1891) Centr. f. prakt. Angenh'k. d., p. 43.

11. Gepner: (1.891) "Fin Fal! von Bindeliautlupus, nach dem Koch'schen Verfahren behandelt." Cent. f. prakt. Augenh'k'd., $x \mathrm{x}, \mathrm{p} .1-7$.

12. Gradle: (1891) "The Curative Influence of Tuberculin on a Certain "Type of Corneal Uiceration." The Chicago Med. Rec. II, p. $544-549$.

13. v. Hippel • (1891) "Aus der Klinik. 1. Augenheilkunde. Klin. Jahr. (Frganzungband), p. 692.

14. Knenigshoefer and Mascluke: (1S91) "Becbachtungen iiber die Wirkung des Koch'schen Heilnittels bel Augenerkrankungen." Deuts. med. Woch., No. 2, p. 72-77. 
local and general reaction. (5) Ulcers of $2 \mathrm{~mm}$. and less healed in 2 days by $1 / 2 \mathrm{mg}$., with local and general reaction. (6) Large ulcer healed in 6 days by two injections of $1 / 2 \mathrm{ms.}$, with local and general reaction. (7) Iris nodes almost entirely absorbed in 10 days by three injections of $1 / 2$ to $1 \mathrm{mg}$. (8) Large nodes on lid margins of each eye absorbed in five days by two injections of $1 / 2$ and $1 \mathrm{mg}$; temperature reaction only. (9) Small tumor of tarsal conjunctiva absorbed in 7 days by two injections of $1 / 2$ and I $\mathrm{mg}$., with local and general reaction.

LANDGRAF ${ }^{15}$ reported a case of granuloma tuberaulosum filling one-half of anterior ciramber and invading the ciilary body, reduced to a minimum by 24 almost daily injections of $1 / 1000$ to $1 / 500 \mathrm{mg}$, with local and general reantion.

LEBER ${ }^{1 "}$ reported a ease of nodes over the whole iris resorbed without a trace in 7 weeks by 10 injections of $1 / 1000$ to $8 / 1000 \mathrm{mg}$. extending over but 4 weeks; local and general reaction.

MIKulicz ${ }^{2 \pi}$ reported fresh phlyctenule caused by tuberculin injections for a tubercular elbow joint.

Pflueger ${ }^{18}$ reported conjunctival tuiveraulosis, with loca! and general reaction on each of 12 injections $(1 / 500$ to a few mg.), with increase in the size of the tubercular areas.

SATTLER $^{\text {io }}$ reported three cases: (1) Tuberculous nodes and ulcer of palpebral conjunctiva, corrovorated by Cohnheinis experiment, permanently healed by 15 injections of $3 / 200$ to $1 / 4$ mg. (2) 'Trachoma-follicle-like fornix tubercular nodes, corroborated by Cohnheim's experiment, healed by 10 injections of 1 to $10 \mathrm{mg}$. (3) Lupus conjunctiva, corroborated iny Colinheim's experiment, without definite results in the lime treated.

ScILAFFrANEK ${ }^{20}$ reported a case of $\mathrm{lid}$ and correal disease entirely relieved by 4 injections of $1 / 1000$ to 8,1000 ing. in 4 weeks, with local and general reaction.

SonwanN ${ }^{21}$ reported an almost lens-sized corneal ulcer healed in 15 days by 6 injections of $1 / 1000$ to $\pi / 1000 \mathrm{mg}$, with local and general reaction.

SCHWEIGXER ${ }^{22}$ reported three cases: (1) Caries and abscess of the lower orbital margin healed completely in 2 weeks by 3 injections of 1.5 to $4 \mathrm{mg}$, with local and general reaction. (2) Corneal infiltration and eczema much improved by 2 injections of 2 and $5 \mathrm{mg}$. in ten days, but with no decided local or general reaction. (3) Lachrymal disease, with no reaction or improvement on 7 injections of 1 to $10 \mathrm{mg}$. (4) Blennorrhei of the sac, with possible bone disease, without local reaction or improvement, though general reaction on 2 injections of 5 mg. each.

SiLEX ${ }^{23}$ reported lupus of face and lids somewhat improved at first by the injections, but much worse later, and somewhat improved finally by other treatment; $120 \mathrm{mg}$. in all were used.

UnTHOFF ${ }^{24}$ used $1 / 5000$ to $1 / 1000 \mathrm{mg}$. injections in 10 cases of phlyctenulæ, keratitis superficialis vascularis, keratitis fassicularis, corneal ulcer, etc., with general reaction in all, but local reaction in only 3 , and a generally favorable and prompt result in the treatment.

15. IAandgraff: (18.91) "Tuberculose Geschwulst der Urea, mit Koch'seher Fluessigkeit behandelt." Berl. klin Woch., No. 11, p. $285-296$.

16. Leber: (1801) "Ueber abgeschwaechte Tuberculose des Aures." Bericht d. xxi. Ophth. Gesell. zu Heidelberg, p. 44-60. 17. Mikulicz: (1891) Quoted by Cohn, Berl. klin. Woch., No. 7, p. 175 .

18. Pflueger: (1891) Eericht d. xxi Ophth. Gesell. Zu Feidelberg, p. $67-70$.

19. Sattler : (1891) "Ueber die Behandlung der verschleden Formen der Conjunctival-Tuberculose mit Tubercultn nebst exper1mentellen Untersuchungen iiber die Wirkung derselben." Bericht d. xxi, Ophth. Gesell. zu Heldelberg, n. 33-44.

20. Schaffranek: (1891) "Weitere Mittheilungen uber die mit dem Tuberculin gewonnen Erfahrungen." Deut. med. Woch., No. 32, p. $1199-1200$.

21. Schwann: (1891) "Fall von tuberculoesem Hornhautgeschwuer des rechten Auges. Hellung nach 6 Injectionen." Deut. med.

Woch., No. 3 , p. 116-117.

22. Schwelgger: (1891) "Aus der Klinnik f. Augenkranke. Klin. Jahr. (Ergaenzungshand), p. 220-224.

23. Silex: (1891) "Robert Koch's neues Heilverfahren." Deut. med. Yelt., p. 165, and Allgem. med. Central-Zeltung, p. 386-387.

24. Uhthoff : (1891) "Ein Beftrag zur Behandlung Augenkranker nach dein Kochltschen Verfabren." Berl. klin. Woch., No. 7, p. 1722 .
WAGNER $^{25}$ reported four cases: (1) Three cases of lupus of the lid skin, with fistulous dacryocystitis, healed by 25 injections of $1 / 200$ to $30 \mathrm{mg}$, with local and general reaction in each. (2) Tuberculous vlcer of palpebral conjunctiva, cured in 4 weeks by 2 injections of $1 / 1000$ to $1 / 500 \mathrm{mg}$., with teinperature reaction. (3) Node-form tubercular scleritis cured in 6 weeks by injections of $1 / 200 \mathrm{mes}$., incretsed by $3 \mathrm{mg}$. each dose, with loeal and general reaction. (4) Tubercular iris nodes reduced to a minimum by injections of $7 / 1000$ to $1 / 10$, with local and general reaction.

Subsequent to 1891 we find the following reports:

$\mathrm{HAASE}^{26}$ reported a case of iridocyclitis tuberculosa, with general but no local reaction on 9 injections of 1 to $4 \mathrm{mg}$. extending over 2 months; though the nodes disappeared two months Iater, the author thinks it was not due to tie tuberculin.

$\mathrm{KUNZ}^{27}$ recommends the use of tuberculin for diagnostic purposes.

ZTMMERMANis ${ }^{28}$ reported the case of a patient with severe tuberculosis of the eye. confirmed by a histologic examination, cured by injections of $1 / 500 \mathrm{mg}$; the fellow eye had been removed five years before.

GRADLE $^{28}$ used tubereuin in 4 cascs of interstitial keratitis, with positive febrile reaction in all.

Rermar $^{30}$ reported that two nontss' use of tubereulin $(6 / 10000$ to $1 \mathrm{mg}$.) had no essential local or general effert or curative action in a case of tiberculosis of the conjunctiva with bacilli on histologic examination and with positive inoculation experiments.

Scirmec ${ }^{31}$ studied the subject very carefully and reported 5 cases, with a general favorable result, as follows: (1) A large iris node disappearing under injections of $1 / 10$ to $5 \mathrm{mg}$. of the old tuberculin during 6 montis, with recurrence and resorption, and a second recurrence and resorption by $1 / 500$ to $4 \mathrm{mg}$. of the new tuberculin T. R., with final quiescence of 2 months; temperature reaction. (2) Iris angle nodes disappearing on 2 injections of $1 / 5$ to $1 / 2 \mathrm{mg}$., with extensive recurrence over $2 / 3$ of iris and resorption in 5 months by $1 / 20$ to 5 mg. and even $18 \mathrm{mg}$., withont essential local or general reaction; second recurrence over two-thirds of jris and tinal resorption after 2 monthy of $1 / 2$ to $5 \mathrm{mg}$., and nine and one-haif years of quiescence (v. Hippel). (3) Iritis plastica treated 5 weeks by $1 / 2$ to I mg. injections, withont iocai or general reaction or improvement, but with the development of lupus nodes; all were later cured in 4 weeks under expectant treatment. (4) Iris node in each eye with derelopment of a nylo. pyon under $1 / 200$ to $7 / 10 \mathrm{mg}$. injections extending over 3 weeks and subsequent absorption of hypopyon and noiles under expectant treatment, with 2 years of quiescence. (5) Iris and corneal nodes entirely absorbed uncier 24 mjections of $1 / 500$ to. $1 \mathrm{mg}$. in three months, with no local or general reaction; 5 years of quiescence.

Uнтाіо $\mathrm{FF}^{32}$ contributed a notable case of conjunctival tuberculosis, in which the nodes excised gave a positive experimental tuberculosis in a rabbit and tubercle bacilli were found on anatomic study, yet a careful tuberculin test with 2 injections of $1 / 10$ and $0.000375 \mathrm{mg}$., respectively, gave no local reaction, though some temperatire reaction. The disease was not influenced.

25. Wagner, $H .:$ (1891) "Dle Tuberculose des Auges und der Erfolg der Anwendung des Koch'schen Tuberculins bel derselben." Muench. med. Woch., No. 15, p. 266-268, and No. 16, p. 286.287 26. Haase: (1893) "Ueber Tuberculose des vorderen Tractu" uvealls." Inaug. Diss. Kiel., 33 pages.

27. Kunz: (1899) "Ueber die Tuberculose des Auges und selner Adnexe." Inaug. Diss., Marburg.

28. Zimmermann: (1898) "Experimentelle und auatomische Untersuchungen iber die Einwirkung der neuen Koch'schen Tuberculinpraeparate." Dle Ophth. Klinik, Nos. 8 and 9 , p. 144-148, and No. 10, p. 172-175.

29. Gradle: (1900) "Scrofulous Keratitis." Trans. Sect. on Ophth. 51st Meeting of the A. M. A., p. 44-53.

30. Reimar: (1900) "Casuistische Beitraege zur Conjunctival tuberculose." Klin. Monatsbl. f. Augen., xxxvili, p. 83-96.

31. Schleck: (1900) "Klinische und experimentelle Studien über die Wirkung des Tuberculins auf die Iristuberculose." Arch. 1 . Ophth. 1, 2, p. 247-359.

32. Uhthoff: (1900) "Bemerkingen 7ur Scrophulose und Tuberculose nebst elnem Beitrag zur Tuberculose der Conjunctiva." Ferl. klin Woch., No. 50, N. 1144-1148. 
Morax and Cilaillous ${ }^{33}$ reported three cases: (1) 'Tuber: culous nodes over one-half of the cormea and on the lids of each eye absorbed in two weeks after an injection of tuberculin, with a local and general reaction. (2) Iris nodes absorbed in six weeks after one injection of $1 / 20 \mathrm{mg}$, accom. panied by both local and general reaction. (3) Nodes in the cornea absorbed on one injection of $1 / 20 \mathrm{mg}$. and the use of mercury and potassium iodid.

FALCKENBERG 3 reported cases of iris and choroidal, as well as probable bone tuberculosis. No improvement after one month of $1 / 500$ to $1 / 50 \mathrm{mg}$. injections, though there was both. local and general reaction, and inoculation experiments were positive. The eye was enucleated following a spontaneous perforation, and the patient died one month later from meningitis. (2) Iritis tuberculosa, with no improvement or local or general reaction on 10 injections of $1 / 500$ to $1 / 20 \mathrm{mg}$. during 18 days, and enucleation followed by death one month later from meningitis. No bacilli were found, though inoculation experiments were positive. Falckenberg says he thinks the doses were not sufficiently large or numerous.

$\mathrm{HAAB}^{35}$ used tuberculin for diagnostic purposes in many cases in which the diagnosis was not clear, among them two cases of iritis tuberculosa, with marked Iocal reaction in the nodes, as well as the febrile reaction.

ENSLIN $^{36}$ obtained a typical tuberculin temperature reaction in 8 cases of keratitis parenchymatosa, and with local reaction in some of them by $1 / 10$ to $3 \mathrm{mg}$. injections; also in a case of conjunctival tuberculosis and in a case of iris tuberculosis.

HANDMANN ${ }^{37}$ reported two cases: (1) Iris angle nodes reduced to $1 / 2$ or $2 / 3$ by 9 weeks of injections of $1 / 1000$ to $3 \mathrm{mg}$., and completely absorbed one and one-half years later. (2) Iris nodes in each eve absorbed with scarcely a trace left after 10 weeks of $1 / 100$ to $2 \mathrm{mg}$. Local and general reantion.

KrUECKMANN ${ }^{39}$ considers the diagnostic value of tiberculin to be very great in doubtful cases.

v. MrCHEL ${ }^{39}$ saw small nodes appear on the iris and selera a few hours after an injection of tuberculin in iritis.

Petella ${ }^{40}$ used tuberculin $T$. $R$, for diagnostic and partly for therapeutic purposes in two cases, one of conjunctival tuberculosis, and recommends it as the most certain diagnostic means.

PFLUEGER ${ }^{31}$ has used tubereulin for diagnostic purposes for the past two years with the most satisfactory results. He considers its diagnostic reaction to be of great weight in doubtful cases.

SALIE $^{42}$ reported three cases: (1) Tubercular tarsaI-conjunctival excrescences absorbed in 7 weeks by 10 injections of $1 / 500$ to $6 / 500 \mathrm{mg}$. with slight local and general reaction; recurrence with a $4 \times 1 \mathrm{~mm}$. ulcer the following year, again healed by injections. (2) Tarsal conjunctival excrescences and ulceration healed by 25 injections of $1 / 500$ to $21 / 550 \mathrm{mg}$. in three months. Inoculation experiments were positive. (3) Tubercular granulations and ulcer of the tarsal conjunctiva slowly healed by 61 injections of $1 / 500$ to $21 / 50 \mathrm{mg}$, along with 5 cauterizations extending over 4 months. Inoculation experiments were positive.

33. Morax and Challlous: (1901) "Le diagnostle des affections tuberculeuses de l'appareil visuel." Ann. d'Ocul., cxxvi, p. 119 132.

34. Folckenberg: (1901) "Fin Beitrag zur Pathologie und Theraple der Iridocyclitis tuberculosa." Inaug. Diss. Tuebingen, 24 pages.

35. Haab: (1902) "Tericht über d. $\mathbf{x} x \mathbf{x}$ Vers. d. Ophth. Gesell, zu Heldelberg p. 131.

36. Enslin: (1902) "Ueber die diagnostlsche Bedeutung des Tuber'ulin auf ophthalmologischen Gebiete." Allgem. med. Central Zeit., No. 94, p. 1115-1116.

37. Handniann : (1902) "Zur Behandlung der Iristuberculose mit ruberculin-TR": Kun. MonatsbI, f, Auren., xl, if, p. 219-227. 38. Krteckmann: (1902) "Ueber Iridocyclitis syphilitica Bericht d. xxi Vers. d. Ophth. Gesell. zu Heldelberg, p. 117-133.

39. Michel: (1902) Bericht iiber d. xxx Vers. d. Ophth. Gesell,

zu Heidelberg, p. 132 .

40. Petella: (1902) "Sulla tuberculosi della conjuntive oculopalpebrale." XVI Congresso dell' Assoc. oftalm. Ital. and Annal di Ottalin. e Lavori della Clinica Oculisticadi Napoli xxxi, p. 731. Rev. in Arch d'Ophth., xxtil, July, 1903, p. 484.

41. Fulueger: (1902) Bericht iber d. xxx Vers d. Ophth. Gesell. zu Heldelberg, p. 131 .

42. Salle: (1902) "Ueber die Frfolge der T'uberculinbehandlung bei Conjunctival-Tuberculose." Inaug. Diss. Goettingen, 37 pages.
DARIER ${ }^{3}$ reported a case of interstitial keratitis treated with good results; the cornea cleared after a number of injections. There were marked local reactions.

ENSLIN ${ }^{\text {ts }}$ used tuberculin as in differential diagnostic means between lues and tuberculosis in 24 cases of keratitis parenchymatosa; five gave the typical local and general reaction.

$\mathrm{HAAB}{ }^{15}$ used tuberculin for diagnostic purposes with positive results in suspected tuberculosis of the conjunctiva 2 ; of the lachrymal gland 1 ; in severe corneal eczema 1 ; iritis with and without definite nodes 9 ; conglomerate tubercle of the choroidea 1; choroiditis 3 ; ; neuroretinitis 2 ; choked disc 2 . He obtained the local diagnostic reaction in each case. He saw improvement from tuberculin therapy in uveal tuberculosis a nodular tubercular iridochoroiditis entirely cured by 14 injections, and a choroiditis with striking local reaction, though no curative results, on 4 injections.

Morinamis reported that Kayser says he obtained a local and general reaction in three cases of a chronic type by the use of 1 to $3 \mathrm{mg}$. of tuberculin.

WEIGELT ${ }^{47}$ reports a large iris tubercle markedly reduced in size by 4 weeks' treatment by new tuberculin, although several smaller nodes appeared in other parts of the iris.

DupuY-Dutemps ${ }^{+8}$ reported that the results of tuberculin are sometimes unsatisfactory.

Groenouw ${ }^{49}$ speaks at length of the diagnostic and therapentic use of tuberculin.

Hess $^{50}$ has treated 9 cases of iritis tuberculosa with tuberculin $T$, R. with a favorable result in all, and an unfavorable result in none. He says tuberculin should find more extended systematic use as a diagnostic means.

v. HIIPPEL ${ }^{51}$ reported ten cases: (1) Iris nodes each eye absorbed by 26 injections of $1 / 500$ to $1 / 12 \mathrm{mg}$. in two months; recurrence $4 \frac{1}{2}$ years later with perforation of the cornea; nodes absorbed after 33 injections, though phthisis bulbi was inevitable in one eye. (2) Iris nodes absorbed in 7 weeks by 23 injections of $1 / 500$ to $1 \mathrm{mg}$., with 4 years quiescence. (3) Iris nodes absorbed by 56 injections of $1 / 500$ to $1 / 50 \mathrm{mg}$. in $41 / 2$ months, with 2 years of quiescence. Histologic corroboration later by Schmidt-Rimpler. (4) Severe corneal and iris tuberculosis with nodes absorbed by 36 injections of $5 / 500$ to $6 / 50 \mathrm{mg}$. in 3 months. (5) Iris nodes disappeared on 69 injections of $1 / 500$ to $9 / 50 \mathrm{mg}$. in 1 month. (6) Primary tuberculosis of ciliary bodies; iris nodes absorbed and cyclitis completely cured by 68 injections of $1 / 500$ to $40 / 50 \mathrm{mg}$. in 5 months. (7-9) Three cases of severe conjunctival tuberculosis permanently healed by tuberculin without lid malposition, after resisting 6 months of other treatment. (10) Severe scleral tuberculosis and corneal nodes absorbed by $1 / 500$ to $1 / 5 \mathrm{mg}$. Recurrence and cure after more injections, with 6 months' quiescence.

v. MrcheL ${ }^{52}$ remarked that he had seen very severe local and general reaction in iritis tuberculosis after tuberculin in. jections. A severe pneumonia followed an injection in disease of the lachrymal sac. The persons affected were not especially weak persons. He warns against the therapeutic use of tuberculin, and says it is preferably used for diagnostic purposes.

43. Darier: (1903) "Subconjunctival Injections of Tuberculin T. R. :n the 'Treatment of Interstitial Keratitis." Brit. Med. Jour. September 26 , p. 721-722.

44. Enslin : (1903) "Ueber die diagnostische Verwertung des AItTuberculins bel der Keratitis parenchymatosa." Deut. med. Woch., No. 8, p. 130-133, and No. 9 , p. 155-157.

45. Haab: (1903) "Ueber die Anwendung des Tuberculins bel Augenerkirankungen." Corresp. f. S. Aertze, No. 21, p. 725-730.

46. Morinami: (1903) "Beltraege zur Theraple und Diagnose der Augentuberculose." Inaug. Diss., Rostock. klin. Manatsbl. $\ell$. Augenh'l'k., xllt, 1, p. 115-123.

47. Woigeit: $(1902)$ "I 'is-tuborkel mit Neu-tuberculin behandelt." Die Ophth., Klinik, S. 372.

48. Dupuy Dutemps: (1904) "Tuberculose der Cherloldea." See lslin Monatsbl. t. Augenh'l'k., xlii, Part I, p. 103 .

49. Groenouw : (1904) "Tuberculose," Handbuch d. gesamt. Au genheilkunde, 2d Ed., vol. xl., Part I, p. 670.737.

50. FIess : (1904) "Tuberculose des Auges." See Klin Monatsbl. f. Augenh'l'k., xllii, I, 115-123.

51. v. Hippel: (1904) "Ueber den Nutzen des Tuberculins bel der Tubarculose des Auges." Arch f. Ophth. 11x, I, p. 1-30.

52. จ. Michel : (1904) "Ueler Versuche mit Tuberculin zu Hellwecken." Klin. Monatsbl. f. Augenh'l'k., xlil, II, p. 145 and 146. 
MorssonnieR:3 recommends the diagnostic use of tuberculin in doubtful eases.

PUCcion ${ }^{54}$ reported that tuberculosis, especially when localized in the anterior chambers, reacted to tuberculin. Later anatomic examinations demonstrated the tubercular nature of the disease.

SchoeleR ${ }^{55}$ used tuberculin methodically to determine the diagnosis in 48 cases, including scleritis, iritis serosa, keratitis parenchymatosa and choroiditis disseminata. He very strongly advised the use of the drug along with and in preference to other means of diagnosis.

\begin{tabular}{|c|c|c|c|c|}
\hline Findings. & $\begin{array}{l}\text { Positive } \\
\text { Diagnosis } \\
\text { Results. }\end{array}$ & $\begin{array}{l}\text { Good Therapeu- } \\
\text { tic Results. }\end{array}$ & \begin{tabular}{|c|} 
Injurious \\
Therapeutic \\
results.
\end{tabular} & $\begin{array}{l}\text { No Thera- } \\
\text { peutic re- } \\
\text { sults. }\end{array}$ \\
\hline $\begin{array}{l}\text { General react- } \\
\text { ion. }\end{array}$ & $\begin{array}{c}\text { G a d l e } \\
\text { Wehrli }\end{array}$ & $\begin{array}{l}\text { v. Hippel (1891) } 2 . \\
\text { Koenigchoefer } \\
\text { \& Maschke } 8 . \\
\text { Wagner 2. } \\
\text { Schieck 1. Stan- } \\
\text { culeano 4,5,6,7,8. }\end{array}$ & $\begin{array}{c}\text { Koehlerd } \\
\text { Westphal. }\end{array}$ & $\begin{array}{l}\text { Cohn } 1,2 \\
\text { Schweigg- } \\
\text { er } 4 . \\
\text { Haase. }\end{array}$ \\
\hline $\begin{array}{c}\text { Loc al reac- } \\
\text { tion. }\end{array}$ & $\begin{array}{l}\text { Pflueger } \\
\text { (1902). } \\
\text { Haab } \\
\text { (1903!. } \\
\text { Hess. } \\
\text { Moisson- } \\
\text { ier. } \\
\text { Schoeler }\end{array}$ & $\begin{array}{l}\text { U h t h o ff (1891). } \\
\text { Darier. Haab } \\
\text { (1903). }\end{array}$ & จ. $\underset{(1902) .}{\mathbf{M i c h}}$ & Haab (1903) \\
\hline $\begin{array}{c}\text { General and } \\
\text { local reac- } \\
\text { tion. }\end{array}$ & $\begin{array}{l}\text { A en oc b } \\
\text { Enslin } \\
\text { (1902) } \\
\text { V. Michel } \\
\text { (1904). } \\
\text { Morina- } \\
\text { mi. }\end{array}$ & 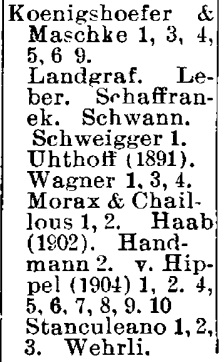 & $\begin{array}{l}\text { B e I li a r d } \\
\text { (Sulzer). } \\
\text { Pflueger } \\
\text { (1891'. } \\
\text { y. Michel } \\
\text { (19n4). }\end{array}$ & $\begin{array}{l}\text { Gradle (1 } \\
1 .\end{array}$ \\
\hline $\begin{array}{l}\text { Tubercle bac- } \\
\text { illi found. }\end{array}$ & & $\cdots \cdots \cdots \cdots$ & & Bongartz. \\
\hline $\begin{array}{l}\text { Positive in } \\
\text { oculation ex- } \\
\text { periments. }\end{array}$ & & $\mid \begin{array}{l}\text { Sattler 1,2. Salie } \\
2,3 .\end{array}$ & & $\begin{array}{c}\text { Enslin(1891) } \\
\text { Sattler 3. }\end{array}$ \\
\hline $\begin{array}{l}\text { Positive in - } \\
\text { oculation ex- } \\
\text { periments } \\
\text { with general } \\
\text { and local tu- } \\
\text { berculin re- } \\
\text { setion. }\end{array}$ & & $\ldots$ & $\begin{array}{l}\text { Falckenberg } \\
\text { 1. }\end{array}$ & \\
\hline $\begin{array}{l}\text { action. } \\
\text { Positive in - } \\
\text { oculationex- } \\
\text { per iments } \\
\text { and tubercle } \\
\text { found. }\end{array}$ & & Albrand. & & $\begin{array}{l}\text { Uhthoff } \\
(1900) . \\
\text { Reimar. }\end{array}$ \\
\hline $\begin{array}{c}\text { found. } \\
\text { No keneral or } \\
\text { local react- } \\
\text { ion or posi- } \\
\text { t1ve inocula- } \\
\text { tion experi- } \\
\text { ments or tu- } \\
\text { bercle found. }\end{array}$ & $\begin{array}{l}\text { Kunz....... } \\
\text { Petella. } \\
\text { Pfineg i r } \\
(1902) .\end{array}$ & $\begin{array}{l}\text { Gepner, Koening- } \\
\text { shoefer \& } \\
\text { Ma:chke } 2,7 . \\
\text { Gradle (18911) 2,3. } \\
\text { Schweigger 2. } \\
\text { Schieck } 2,5 . \\
\text { Morax \& Yhail- } \\
\text { lous 3. Hand- } \\
\text { mann 1. Petella. } \\
\text { Salie 1. Weigelt. } \\
\text { v. Hippel(1891)1. } \\
\text { Hess. Reunert. }\end{array}$ & Nikulicz & $\begin{array}{l}\text { Schweigger } \\
3 . \text { Silex. } \\
\text { Schieck } 3, \\
4 . \text { Falch- } \\
\text { enberg 2, } \\
\text { Dupuy- } \\
\text { Dutemps. }\end{array}$ \\
\hline $\begin{array}{c}\text { Histologic ex- } \\
\text { amin a t i on } \\
\text { revealed tu- } \\
\text { berculosis. }\end{array}$ & Puccioni.. & $\begin{array}{l}\text { Z i m merman an } \\
\text { v. Hippel (1901) } \\
3 .\end{array}$ & & \\
\hline
\end{tabular}

The swal! numbers after the author's names refer to case numbers in their rejorts.

Stanculeano ${ }^{56}$ reported eight cases: (1) Corneal infiltrate markedly improved on 10 injections of $1-5 \mathrm{mg}$. in 8 weeks. Local and general reaction. (2) Similar cases (6 injections during 7 weeks). (3) Keratitis and iritis with im-

53. Moissonnler: (1904) "Irido-cyclite tuberculeuse.", Arch. d'Oph., xxiv, p. 438-455 and Klin. Monatsbl. f. Augenh'l'k., xlii, p. 596 .

54. Pucciont : (1904) "Taberculosi oculare. Clinica oculistica." Mars. p. 1615-1616. Rev. in Revue Gen. d'Ophthalmologie, xxiv, No. 1 , p. 13

55. Schoeler: (1004) "Vorlaenfige Mitteilung über Versuche mit T5. Schoeler : p. 600 and xliii, I, p. $115-123$.

.60 "Recherches diagnostique et therapentigue da la koratite parenchymatem an inoyen de lu tubercupeutique 'T." Ann d'Öul., cxxxii, p. 340-852. provement by 1 injection of $1-5 \mathrm{mg}$., extending over 11 weeks. Local and general reaction. (4) Keratitis and iritis improved by 6 injections of $1-5 \mathrm{mg}$. during 4 weeks. General, but no local reaction. (5) Keratitis, with slight iritis, with general but no local reaction to 4 injections of $1-5 \mathrm{mg}$. (6-8) No local reaction, though reaction on 1 and 2 injections of $1 / 10$ to 2 mg.

$\mathrm{KAYSER}^{57}$ gives an extended review of recent diagnostic and therapeutic measures employed in tuberculosis of the eye, including the use of tuberculin.

WEHRLI $^{58}$ : A case of lupus cornea, with a certain reaction (temperature of 100.4 degrees).

REUNERT ${ }^{5 n}$ : Tuberculous iris nodes completely absorbed in 7 weeks by 6 months of injections ( $1 / 500$ to $1 \mathrm{mg}$.), given every other day, with 4 months of subsequent quiescence. ( $v$. Hippel.)

The accompanying table comprises a summary of the case reported.

\section{CONCLUSIONS.}

There is very little question as to the value and reliability of tuberculin as a diagnostic agent. Failure to obtain the reaction on one injection, however, is not conclusive, and, according to T'inker, ${ }^{60}$ successive doses of 3, 6 and even $9 \mathrm{mg}$. should be used before tuberculosis be considered definitely excluded. Our own experience, however, although confined to but one case, would lead us to recommend that the very lowest possible dose be used in view of the profound general reaction which we have seen with a $5 \mathrm{mg}$. injection. The early view that its use caused a dissemination of the tuberculous material throughout the body has been very much modified in recent years.

Tinker has used it for general diagnostic purposes in over 400 surgical cases, with no untoward results that could be directly attributed to its use. He notes that Virchow's objections were very cautiously expressed and only once, and were based on 21 postmortems made during the first year of the use of tuberculin when very large doses were employed. Even at that time, however, his views were opposed by Ziemssen, Gultmann and Ehrlich, Schede, Curschmann and others. As to its therapeutic value, less may rightly be said, since far too few conclusive cases have as yet been studied, the present case being but the thirty-third detailed report in the literature. Much tuberculous disease of the eve is of a chronic, non-virulent type, with sparse bacilli findings and a more or less pronounced tendency to spontaneous healing, as first pointed out by Leber ${ }^{16}$ (1891). Such patients can certainly be helped by tuberculin, and the series of cases contributed by Schieck ${ }^{31}$ and v. Hippel ${ }^{12}$ in particular show that very advanced tuberculosis can be arrested, improved or entirely cured with years of subsequent immunity.

Professor v. Hippel closes his article with the statement:

"On the ground of the facts which I have contributed I consider it indicated that we possess in tuberculin T. $R$. a means which, if rightly used, will permanently heal the severest tuberculosis of the eye."

57. Kayser: (1905) Ueber die Tuberculose des Auges." Klin. Monatsbl. f. Augenh'l'k., rlill, f, pp. 115-123.

58. Wehrli: (1905) "Die knoetschenfoermige Hornhauttruebung (Groenouw) eine primaere, isolierte, chronische, tuberculoese Erkrankwng der vorderen Schichten der cornea-Lupus corneae." Zeits., f. Augenh'lk'de, No. 4, 1. 322-335; No. 5, p. 461-479; No. 6 , p. $558-578$.

59. Reunert: (1905) "Ueber die durch Tuberculose bedingten pseudo-leukmmische. Erkkrankungen und ihre Behandlung mit Neutruberculin. Unter Mittcilung eines nit In stuberculose komplizier. ter Falles." Dent. med. Woch. xxxi, No. 23, p. 907-110.

60 . 'Tinker : "The Value of "Tuber(1)in in Surgical Diagnosis," Johns Hopkins Reports, vol. ii, 1903, p. 535-565. 
DISCUSSION.

Dr. Albert E. Bulson, Jr., Fort Wayne, Ind., said that he had a similar case of tuberculous iritis under tuberculin treatment at the time, and that he had the pleasure of seeing Dr. Brown's case when it was presented before the Chicago Ophthalmological Society for diagnosis, and at the time suggested the use of tuberculin to establish a diagnosis. He believes that ophthalmologists are apt to be led into error as to the value of tuberculin in establishing a diagnosis unless certain well-defined rules are followed in its use. Dr. Bulson said that while Dr. Brown speaks of using small doses for diagnostic purposes and increasing the dose if no reaction is secured, he is inclined to agree with many observers that a large dose, say from 10 to 12 milligrams, is warranted as an initial diagnostic dose, and if no reaction is secured the dose may be repeated in the course of a few days. Even in the presence of a localized tuberculous infection a small dose of tuberculin may produce absolutely no reaction. It is of the most importance that a record of the temperature for three days prior to the injection be carefully kept for comparison with the record following the injection, as some of these patients having only a localized area of tuberculous infection, as in the iris, will show very little reaction, even with a large dose of tuberculin. On the other hand, a decided reaction should not be accepted as a positive indication that the patient has tuberculosis, for the rise in temperature may be only coincident, as Dr. Bulson has known it to be on two occasions in the practice of one of his confrères. The injections should be sufficiently large and continued over a sufficient period of time definitely to establish the fact that a reaction is or is not being produced by the injections. Syphilis should be excluded, as it has been known to influence reaction from tuberculin injections. The case of tuberculous iritis in a 4-year-old child which Dr. Bulson has under tuberculin treatment at the present time, exhibited a marked reaction on several occasions to injections of 10 milligrams, but has failed to show reaction to doses of half that size. With each injection the eye, which has lost light perception, but gives the patient no discomfort, assumes an angry red appearance, and the seven nodules on the iris become infiltrated and swollen. This local reaction in the eye lasts from twelve to thirty-six hours, leaving the eye about as it was before the injection. Treatment has been carried on regularly for about six weeks, and though the general physical appearance of the patient has improved, the condition of the eye seems to be unchanged. As a means of establishing a diagnosis of tuberculous iritis, the injection of tuberculin is certainly warranted, but as nearly as Dr. Bulson can learn by reference to the literature on the subject, the curative value of tuberculin in these cases depends largely on whether the lesion is localized and on its degree of advancement.

Dr. E. V. L. Brown, Chicago, said that the absolute diagnostic value of tuberculin for tuberculosis, and tuberculosis only, is now very generally accepted. The syphilographers are united on this point. The article by Tinker in Johns Hopkins Hospital Reports is very conclusive, and Dr. Brown thinks, can be relied on as being absolutely diagnostic. In reply to a question, he said that the use of air in the anterior chamber in these cases was reviewed by Kaiser recently in the Klin. Monatsbl. $f$. Augenheilkunde.

\section{PNEUMONIA IN THE YOUNG.* EDWARD F. WELLS. M.D.}

I'tofessor of Clinical Medicine and Assoctate Professor of Practice of Medicine in the College of Medicine of the University of Illinots; Physician to Cook County Hospital. CHICAGO.

Pneumonia is always interesting. In the young, interest is heightened by the statistics and statistical fallacies of its prevalence; by important problems connected with its causation and avenues of bacterial invasion, by modifications in its morbid anatomy and

- Read in the Section on Diseases of Chlidren of the American Medical Association, at the Fifty-sixth Annual Session, July, 1905. symptomatology, by the frequency of serious complications, by the apparent difficulties of diagnosis, by the uncertainties of prognosis, and by the chaotic state in which we find the literature of its management.

To estimate fairly the prevalence and fatality of

TABLF SHOWING IREVALENCE OF PNEUMONIA BY AGE PERIODS.

\begin{tabular}{|c|c|c|c|c|c|c|c|c|c|}
\hline orbidity. & & & & & & & & & Total. \\
\hline duthority & $\begin{array}{r}(b \\
10\end{array}$ & $\begin{array}{l}10 \\
20\end{array}$ & $\begin{array}{l}20 \\
30\end{array}$ & $\begin{array}{l}3: 0 \\
40\end{array}$ & $\begin{array}{l}40 \\
50\end{array}$ & $\begin{array}{l}50 \\
60\end{array}$ & $\begin{array}{l}60 \\
70\end{array}$ & 70 & $\cdots$ \\
\hline uite & 103 & 333 & 437 & 259 & 195 & 83 & 62 & 29 & 1,501 \\
\hline & 100 & 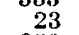 & $\begin{array}{r}62 \\
62\end{array}$ & 38 & 28 & 23 & 5 & 6 & 187 \\
\hline & 7 & $2 \tilde{59}$ & 489 & 259 & 209 & 128 & 92 & 43 & 1,522 \\
\hline nn $\cdots$ & 306 & 257 & $\begin{array}{r}83 \\
156\end{array}$ & 63 & $\begin{array}{r}61 \\
137\end{array}$ & $\begin{array}{l}38 \\
96\end{array}$ & 43 & $\ddot{2} \dot{0}$ & $\begin{array}{r}245 \\
1.176\end{array}$ \\
\hline wn $\quad \ldots$ & & 142 & $\begin{array}{l}100 \\
187\end{array}$ & $\begin{array}{l}161 \\
127\end{array}$ & $\begin{array}{l}137 \\
129\end{array}$ & $\begin{array}{l}80 \\
82\end{array}$ & 40 & 22 & $\begin{array}{l}1,10 \\
750\end{array}$ \\
\hline l & 2 & 21 & 88 & 60 & 41 & 18 & 16 & 2 & 248 \\
\hline & 223 & 28 & $4 \pi$ & 28 & 23 & $\because \dot{6}$ & $\dot{5}$ & $\dot{s}$ & $\begin{array}{l}251 \\
149 \\
\end{array}$ \\
\hline 1 sen & $\frac{4}{8}$ & $\begin{array}{l}33 \\
14\end{array}$ & $\begin{array}{l}4 \\
11\end{array}$ & $\begin{array}{l}28 \\
12\end{array}$ & 23 & $\begin{array}{l}6 \\
4\end{array}$ & ${ }_{2}^{5}$ & $\begin{array}{l}3 \\
1\end{array}$ & $\begin{array}{r}149 \\
56\end{array}$ \\
\hline & $\ldots$ & 13 & 44 & 37 & 17 & 7 & & $\ldots$ & 118 \\
\hline & $\dot{0}$ & 98 & -60 & 182 & 113 & 98 & 121 & $\cdots$ & $\begin{array}{l}872 \\
169\end{array}$ \\
\hline ine & 410 & $\begin{array}{l}47 \\
65\end{array}$ & $\begin{array}{l}46 \\
56\end{array}$ & $\begin{array}{r}204 \\
134\end{array}$ & $\begin{array}{c}14 \\
136\end{array}$ & $\begin{array}{l}11 \\
70 .\end{array}$ & 64 & $\cdots$ & 941 \\
\hline & 57 & 27 & 18 & & 13 & 11 & 2 & & 136 \\
\hline & 10 & 3 & 3 & 11 & 5 & $\bar{b}$ & 5 & 4 & 46 \\
\hline & & 118 & 272 & 175 & 152 & 123 & 63 & 21 & 924 \\
\hline $1 \cdot g$ & $\because$ & 1,500 & 850 & 300 & 500 & 450 & 350 & $5 \overline{5} 0$ & 5,000 \\
\hline$\cdots$ & 448 & $\begin{array}{l}16 \\
52\end{array}$ & $\begin{array}{l}22 \\
\ldots\end{array}$ & $\begin{array}{l}13 \\
\ldots\end{array}$ & $\ldots$ & 6 & $\ldots$ & $\ldots$ & 500 \\
\hline vede & $\begin{array}{l}4+6 \\
15\end{array}$ & 02 & $\cdots$ & $\cdots$ & . & $\cdots$ & & & 15 \\
\hline & 9 & 2291 & 1,041 & 816 & 363 & 125 & 29 & 4 & 2,616 \\
\hline en & 171 & $\begin{array}{l}22 \\
18\end{array}$ & $\begin{array}{l}21 \\
15\end{array}$ & $\begin{array}{l}23 \\
11\end{array}$ & $2 \frac{2}{6}$ & $\begin{array}{r}29 \\
3\end{array}$ & 29 & 13 & $\begin{array}{l}330 \\
106\end{array}$ \\
\hline & 56 & 3 & & & & & & & 59 \\
\hline$n$ & 54 & 34 & 72 & 41 & $\begin{array}{l}37 \\
25\end{array}$ & 23 & $\begin{array}{l}10 \\
23\end{array}$ & & $\begin{array}{l}222 \\
222\end{array}$ \\
\hline Ifosp. & $\begin{array}{r}21 \\
169\end{array}$ & 187 & 143 & 51 & 68 & 32 & & & 651 \\
\hline & 71 & 71 & 136 & 84 & 67 & 30 & 13 & 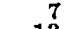 & 479 \\
\hline & 34 & 36 & 15 & 29 & 19 & 9 & 14 & 13 & 169 \\
\hline ith & 95 & 93 & 87 & 62 & 54 & 20 & 18 & $\begin{array}{l}5 \\
3 \\
\end{array}$ & $\begin{array}{r}435 \\
35 \\
4\end{array}$ \\
\hline & $\begin{array}{l}14 \\
158\end{array}$ & 44 & $\ddot{1 \dot{8}}$ & 32 & 38 & 22 & 34 & 11 & 357 \\
\hline & 1 & 25 & 79 & 43 & 30 & 34 & 15 & & \\
\hline ster & 3 & $\begin{array}{l}15 \\
64\end{array}$ & $\begin{array}{r}43 \\
116\end{array}$ & $\begin{array}{l}36 \\
73\end{array}$ & $\frac{24}{41}$ & $\begin{array}{l}18 \\
22\end{array}$ & 12 & $\begin{array}{r}17 \\
1\end{array}$ & $\begin{array}{l}167 \\
\mathbf{3} 31\end{array}$ \\
\hline & 2 & 71 & 73 & 27 & 24 & 26 & 27 & 8 & 258 \\
\hline & 5 & 2 & 3 & 3 & 5 & $2 \frac{2}{27}$ & 4 & $\dot{9}$ & 154 \\
\hline$\ddot{e r}$ & & $20^{4}$ & 31 & 17 & 10 & & & & 83 \\
\hline Ser, D. & 59 & 18 & 80 & 127 & 101 & 71 & $\dot{58}$ & $\dot{48}$ & $\begin{array}{r}173 \\
1120\end{array}$ \\
\hline${ }^{\cdots} \cdot$ & 514 & 116 & 80 & 126 & 101 & 11 & & & 1,120 \\
\hline$\&$ & & 66 & 229 & 241 & 191 & 93 & 48 & 19 & 887 \\
\hline A & & 1 & 18 & 23 & 9 & 5 & 3 & 8 & 434 \\
\hline & 31 & 42 & 12 & 7 & 10 & 5 & 28 & & 407 \\
\hline & $1 \overline{3}$ & 118 & 290 & 90 & 59 & & 24 & 12 & 656 \\
\hline & $\dot{0}$ & $8 \%$ & 67 & 38 & 11 & $\begin{array}{l}27 \\
2\end{array}$ & 22 & & 276 \\
\hline id and & & & & & & & & & \\
\hline idge... & 10 & 113 & 373 & & 11 & 80 & 32 & 12 & 953 \\
\hline Hospital & & & & 231 & 13 & 9 & & 20 & 1,410 \\
\hline & 20 & 20 & (31 & 13 & 06 & 9 & & $\cdots$ & 925 \\
\hline$\ddot{\mathrm{ch}}$ & 4 & $\begin{array}{r}240 \\
10\end{array}$ & 6 & 2 & 13 & $\mathbf{0}$ & & 1 & \\
\hline & $\begin{array}{l}163 \\
367\end{array}$ & 86 & 96 & 51 & 65 & 55 & 113 & $\dot{5} \dot{3}$ & $\begin{array}{l}156 \\
888\end{array}$ \\
\hline Totals & 68 & 111.7 & 21 & 1.84 & 97 & 291 & 5521 & 00 & $\overline{0.025}$ \\
\hline & & & & & & & & 3.5 & 100 \\
\hline
\end{tabular}

Mortality.

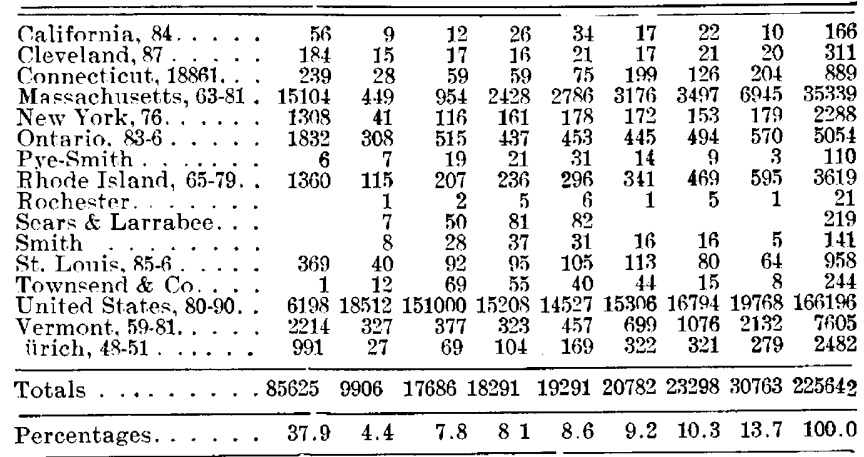

pneumonia in the young is a statistical and judicial feat of no mean proportions. In tabulating and analyzing 30,025 cases of, and 225,642 deaths from pneumonia, the following conclusions may be drawn: During carly childhood pneumonia is encountered oftener than at any other period; from 10 to 30 years, much less 